\title{
Persepsi Peternak terhadap Program Pemurnian Sapi Bali
}

\author{
Ikrar Mohammad Saleh ${ }^{1 *}$, Tanri Giling Rasyid ${ }^{1}$, Ahmad Ramadhan Siregar ${ }^{1}$, Amrullah $^{1}$, \\ Muhammad Hatta ${ }^{1}$, Putra Astaman², Zulkifli Basri ${ }^{3}$ \\ ${ }^{1}$ Fakultas Peternakan, Universitas Hasanuddin, Jl. Perintis Kemerdekaan Km. 10, Makassar 90245 \\ ${ }^{2}$ Program Studi Agribisnis, Fakultas Sains dan Teknologi, Universitas Muhammadyah Sinjai, Sinjai 92615 \\ ${ }^{3}$ Program Studi Agribisnis, Fakultas Pertanian Universitas Al Asyariah Mandar \\ *E-mail: ikrar.saleh@unhas.ac.id
}

\begin{abstract}
Upaya untuk mempertahankan kemurnian Sapi Bali sebagai penghasil daging dengan hasil dan mutu daging yang baik adalah dengan mengetahui persepsi peternak mengenai program pemurnian Sapi Bali. Penelitian ini yang dilakukan bertujuan untuk mengetahui persepsi peternak terhadap pemurnian Sapi Bali di Kecamatan Tanete Riaja Kabupaten Barru Provinsi Sulawesi Selatan. Jumlah populasi pada keempat kelompok tani ternak sebanyak 140 orang. Jumlah sampel sebanyak 58 orang dengan mengunakan rumus slovin dan metode stratified random sampling yang diambil secara acak yaitu Kelompok Tani Ternak Lempangeng 12 orang, Makkawaru 22 orang, Sipurennue 12 orang dan Lempang 12 orang. Data penelitian dikumpulkan melalui wawancara dengan bantuan kuisioner yang diukur dengan menggunakan skala likert yaitu skor 1 sampai 3 dengan kategori 1 = tidak baik; 2 = sedang; dan 3 = baik serta dianalisis dengan menggunakan analisis deskriptif. Hasil penelitian menunjukkan bahwa peternak mempersepsikan dengan baik program pemurnian Sapi Bali karena adanya keuntungan secara ekonomis dan secara teknis yang diperoleh peternak, serta adanya tingkat kesesuaian program dengan kegiatan yang dilakukan oleh peternak.
\end{abstract}

Keywords: Kontrol Perilaku; Norma Subjektif; Peternak; Sapi Bali; Sikap

\section{Pendahuluan}

Sapi potong adalah salah satu ternak penghasil daging di Indonesia, namun hingga saat ini produksi daging dalam negeri 504.802.29 ton belum mampu memenuhi kebutuhan nasional (BPS, 2019). Sapi bali dikembangkan, dimanfaatkan dan dilestarikan sebagai sumber daya ternak asli yang mempunyai ciri khas tertentu dan mempunyai kemampuan untuk berkembang dengan baik pada berbagai lingkungan yang ada di Indonesia (Hikmawaty, dkk., 2014). Sapi bali merupakan plasma nutfah aset negara yang perlu dilestarikan. Pemerintah memberikan perhatian cukup besar sejak lama bagi pelestarian sapi bali dengan menetapkan program nasional pemuliaan untuk sapi bali (Mansur, dkk., 2016).

Jika ditinjau dari segi pelestarian keanekaragaman sumber daya alam, maka upaya-upaya mempertahankan kemurnian sapi bali justru mempunyai nilai tinggi. Potensi sapi bali sebagai penghasil daging yang memberikan hasil dan mutu daging yang baik dan memberikan harapan untuk dikembangkan menjadi tipe daging yang bermutu prima adalah cukup menjanjikan (Ardika, 2016). Terlepas dari potensi sapi bali, yang menjadi penting adalah persepsi peternak mengenai program pemurnian sapi bali.

Persepsi adalah proses yang menyangkut masuknya pesan atau informasi kedalam otak manusia, melalui persepsi manusia terus menerus mengadakan hubungan dengan lingkungannya.hubungan tersebut dilakukan melalui inderanya yaitu penglihatan, pendengar, peraba, perasa dan pencium (Ahmad, 2020). Persepsi merupakan proses akhir dari pengamatan yang diawali oleh proses pengindraan, yaitu proses diterimanya stimulus oleh alat indera, kemudian ada perhatian, lalu diteruskan ke otak, dan baru kemudian individu menyadari tentang sesuatu yang dinamakan persepsi. Dengan persepsi individu menyadari dapat mengerti tentang lingkungan yang ada di sekitarnya maupun tentang keadaan lingkungan yang ada di sekitarnya maupun tentang hal yang ada dalam diri individu yang bersangkutan.

Sehingga persepsi dapat diartikan sebagai proses diterimanya rangsang melalui panca indra yang didahului oleh perhatian sehingga individu mampu mengetahui, mengartikan, dan menghayati tentang hal yang diamati, baik yang ada di luar maupun di dalam diri individu (Puspa, dkk., 2015). Penelitian ini bertujuan untuk mengetahui persepsi peternak terhadap pemurnian Sapi Bali di Kabupaten Barru.

\section{Metodologi}

Penelitian ini dilaksanakan di Desa Lompo Tengah dan Desa Lempang Kecamatan Tanete Riaja Kabupaten Barru Provinsi Sulawesi Selatan. Lokasi ini dipilih secara sengaja karena masih mempertahankan pemurnian Sapi Bali.

Jenis penelitian ini adalah penelitian merupakan deskriptif yang berbasis kelompok tani ternak dengan jumlah populasi peternak Sapi Bali sebanyak 140 orang peternak. Penentuan jumlah sampel menggunakan rumus slovin dan metode stratified random sampling (Sugiono, 2018) yaitu:

$$
n=\frac{N}{1+N \cdot e^{2}}
$$

Dimana: $\quad \mathrm{n}=$ jumlah sampel

$\mathrm{N}=$ jumlah populasi

$\mathrm{e}^{2}=$ prepesisi (tingkat kelonggaran yang ditetapkan sebesar 10\%) 


$$
\begin{aligned}
& =\frac{140}{1+140(0,1)^{2}} \\
& =\frac{140}{1+140(0,01)} \\
& =\frac{140}{2,4} \\
& =58,3 \text { atau } 58 \text { orang. }
\end{aligned}
$$

Sehingga sampel penelitian ini sebanyak 58 peternak Sapi Bali. Jumlah sampel masing-masing kelompok tani ternak yang diambil secara acak adalah:

$$
\begin{array}{ll}
\text { Kelompok Lempangeng } & =\frac{28}{140} \times 58=11,6=12 \text { orang } \\
\text { Kelompok Makkawaru } & =\frac{52}{140} \times 58=21,5=22 \text { orang } \\
\text { Kelompok Sipurennue } & =\frac{30}{140} \times 58=12,4=12 \text { orang } \\
\text { Kelompok Lempang } & =\frac{30}{140} \times 58=12,4=12 \text { orang }
\end{array}
$$

Pengumpulan data melalui wawancara dengan bantuan kuisioner yang diukur dengan menggunakan skala likert yaitu skor 1 sampai 3 dengan kategori 1 = tidak baik; 2 = sedang; dan 3 = baik. Data yang dikumpulkan dianalisis dengan menggunakan analisi deskriptif.

Variabel persepsi peternak diukur dengan menggunakan rentang kelas sebagai berikut:

Skor tertinggi $=$ Bobot tertinggi $\mathrm{x}$ jumlah responden $\mathrm{x}$ jumlah pertanyaan (3) x (58) x (3)

$=522$

Skor terendah $=$ Bobot terendah $\mathrm{x}$ jumlah responden $\mathrm{x}$ jumlah pertanyaan (1) x (58) x (3)

$$
=174
$$

Rentang Kelas $=\underline{\text { Skor tertinggi }- \text { Skor terendah }}$

$$
=\underline{522-174}
$$

Jumlah Kelas 3 Sehingga dapat dibuat kategori dengan rentang kelas sebagai berikut:

$\begin{array}{ll}\text { Baik } & =406-522 \\ \text { Sedang } & =290-406 \\ \text { Tidak baik } & =174-290\end{array}$

Persepsi berupa tanggapan yang diberikan peternak terhadap program pemurnian Sapi Bali di Kabupaten Barru. Deskripsi variabel persepsi peternak terhadap program pemurnian Sapi Bali yang terdiri dari sub variabel: (a) keuntungan secara ekonomis, (b) keuntungan secara teknis, dan (c) tingkat kesesuaian dengan masyarakat setempat. Uraian hasil penelitian terhadap variabel persepsi peternak dapat dilihat pada Tabel 1 .

\section{Hasil}

Tabel 1 menunjukkan bahwa total skor penilaian persepsi peternak terhadap program pemurnian Sapi Bali yang terdiri dari sub variabel: (a) keuntungan secara ekonomis, (b) keuntungan secara teknis, dan (c) tingkat

\begin{tabular}{|c|c|c|c|c|c|}
\hline No & Variabel Persepsi Peternak & Skor & Frekuensi (Orang) & Persentase $(\%)$ & Bobot (skor x frekuensi) \\
\hline \multirow[t]{5}{*}{1.} & Keuntungan secara ekonomis & & & & \\
\hline & Baik & 3 & 45 & 77,59 & 135 \\
\hline & Sedang & 2 & 12 & 20,69 & 24 \\
\hline & Tidak baik & 1 & 1 & 1,72 & 1 \\
\hline & Jumlah & & 58 & 100 & 160 \\
\hline \multirow[t]{5}{*}{2.} & Keuntungan secara teknis & & & & \\
\hline & Baik & 3 & 32 & 55,18 & 96 \\
\hline & Sedang & 2 & 25 & 43,10 & 50 \\
\hline & Tidak baik & 1 & 1 & 1,72 & 1 \\
\hline & Jumlah & & 58 & 100 & 147 \\
\hline \multirow[t]{6}{*}{3.} & $\begin{array}{l}\text { Tingkat kesesuaian dengan } \\
\text { masyarakat setempat. }\end{array}$ & & & & \\
\hline & Baik & 3 & 48 & 82,76 & 144 \\
\hline & Sedang & 2 & 10 & 17,24 & 20 \\
\hline & Tidak baik & 1 & 0 & 0 & 0 \\
\hline & Jumlah & & 58 & 100 & 164 \\
\hline & \multicolumn{3}{|c|}{ Total Skor } & & 471 \\
\hline
\end{tabular}
kesesuaian dengan masyarakat setempat adalah 471. Hasil penelitian ini berada pada Kategori Baik (1400 - 1800). Hasil penelitian ini dapat menunjukkan bahwa peternak Sapi Bali memberikan persepsi yang baik terhadap program pemurnian Sapi Bali. Persepsi yang positif akan memberikan motivasi bagi peternak untuk meningkatkan produktivitas dan keberlanjutan usaha ternak sapinya (Inggriati dkk. 2018).

Tabel 1. Persepsi Peternak terhadap Program Pemurnian Sapi Bali di Kabupaten Barru.

Sumber : Data penelitian setelah diolah, 2021

Peternak memberikan pernyataan bahwa dengan melakukan pemurnian Sapi Bali berarti turut serta mempertahankan predikat Kabupaten Barru sebagai kabupaten yang melaksanakan pemurnian Sapi Bali di Sulawesi Selatan. Terdapat tujuh kawasan pengembangan sapi Bali di Indonesia, salah satunya ialah Kabupaten Barru (Hajirin dkk. 2020). 
Persepsi Peternak terhadap Program Pemurnian Sapi Bali di Kabupaten Barru.

Mansur dkk. (2016) mengungkapkan Program pemurnian dan peningkatan mutu genetik sapi Bali dilaksanakan dengan penetapan wilayah peternakan murni sapi Bali di Sulawesi Selatan khususnya Kabupaten Barru dan Bone.

Selain hal tersebut, peternak merasa bahwa dengan program ini dapat memberikan keuntungan ekonomis karena melalui program ini dilakukan pembiakan Sapi Bali melalui inseminasi buatan (IB) sehingga dapat menghasilkan anak sapi yang dengan sendirinya memberikan keuntungan bagi peternak. Nursida dan Sanusi (2020) menyatakan bahwa Tingkat keberhasilan IB pada sapi betina sangat ditentukan oleh faktor kulitas semen beku maka dari itu, kualitas semen harus tetap diperhatikan agar fertilitasnya tetap baik.

Melalui program ini, peternak menerima transfer teknologi berupa teknik IB, manajemen pembiakan Sapi Bali, pemberian pakan, dan penanganan masalah Kesehatan dan penyakit. Program ini melibatkan banyak stakeholder salah satunya ialah pemerintah, melalui penyuluh yang memberikan pemahaman bagi peternak bagaimana melakukan manajemen peternakan yang baik. Hal ini sejalan dengan Talibo dkk. (2017) hasil penelitiannya menunjukkan bahwa peran penyuluh dalam membimbing dan melatih peternak dalam keterampilan teknis, serta peran penyuluh dalam memberikan berbagai informasi pengetahuan teknis mencakup teknologi yang dibutuhkan peternak.

\section{Kesimpulan}

Hasil penelitian ini dapat disimpulkan bahwa peternak mempersepsikan dengan baik program pemurnian Sapi Bali karena adanya keuntungan secara ekonomis dan keuntungan secara teknis yang diperoleh peternak, serta adanya tingkat kesesuaian program dengan kegiatan yang dilakukan oleh peternak.

\section{Ucapan Terima Kasih}

Penulis mengucapkan terima kasih kepada:

1. Rektor Universitas Hasanuddin melalui Lembaga Penelitian dan Pengabdian Kepada Masyarakat (LPPM) Universitas Hasanuddin dan Dekan Fakultas Peternakan Universitas Hasanuddin yang telah memberikan kepercayaan kepada penulis untuk melaksanakan penelitian ini melalui skema Penelitian Dasar Unhas (PDU).

2. Dinas Pertanian Kabupaten Barru yang telah memberikan izin penelitian kepada penulis.

3. Ketua dan anggota kelompok tani ternak Leppangeng, Makkawaru, Sipurennue dan Lempang yang telah meluangkan waktunya untuk mengikuti FGD dan wawancara.

\section{Datar Pustaka}

Ahmad, A., 2020. Persepsi peternak sapi potong terhadap upaya pemerintah dalam peningkatan mutu bibit ternak hasil program inseminasi buatan di kecamatan sinjai barat kabupaten sinjai. Jurnal Agrominansia, 5(1), 74-88.

Ardika, N., 2016. Pemurnian dan pengembangan mutu genetik sapi bali di bali. Bali. Universitas Udayana. Bali.

Badan Pusat Statistik. 2019. Produksi Daging Sapi menurut Provinsi. 20092019. Jakarta. Badan Pusat Statistik.

Hajirin, Hubeis, M., dan Suryahadi. 2020. Strategi Pengembangan Sap Potong di Wilayah Pengembangan Sapi Bali Kabupaten Barru. Manajemen IKM, Februari 2020 (48-61) Vol. 15 No. http://journal.ipb.ac.id/index.php/jurnalmpi/

Hikmawaty, Gunawan, a., Noor, R. \& Jakaria, 2014. Identifikasi ukuran tubuh dan bentuk tubuh sapi bali di beberapa pusat pembibitan melalui pendekatan analisis komponen utama. Jurnal Ilmu Produksi dan Teknologi Hasil Peternakan. 02(1), 231-237.

Inggriati, Ni Wayan T., Yupardhi, W. S. dan Warmadewi, D. A. 2018 Persepsi Peternak Terhadap Pemanfaatan Sapi Sebagai Atraksi Wisata di Kabupaten Tabanan Bali. Semnas Persepsi III Manado.

Mansur, M. et al., 2016. Keragaman genetik sapi bali di kabupaten barru berdasarkan karaketristik fenotipe dan dna penciri mikrosatelit. JITP. 4(3), 104-111.

Nursida, dan Sanusi, I. 2020. Persepsi Peternak dan Penyuluh LapanganTentang Faktor-Faktor Yang Berpengaruh Terhadap Keberhasilan Upsus Siwab di Kabupaten Kutai Timur. Jurnal Pertanian Terpadu 8 (1): 14-26, Juni 2020.

Sugiyono. 2018. Metode Penelitian Pendidikan Pendekatan Kuantitatif, kualitatif, dan R\&D. Bandung: Alfabeta.

Talibo, R., Sondakh, B. F. J., Sajow, A. A. Lainawa, J. 2017. Analisis Persepsi Petani Peternak Sapi Potong Terhadap Peran Penyuluh Di Kecamatan Sangkub Kabupaten Bolaang Mongondow Utara. Jurnal Zootek ("Zootek" Journal) Vol. 37 No. 2 : 513-525 (Juli 2017). 